UDC 577.15

\title{
PROTEOLYTIC ENZYMES IN CHEESE MAKING
}

\author{
Aktayeva S. ${ }^{1}$, Akishev Zh. ${ }^{1,2}$, Khassenov B. ${ }^{1}$ \\ ${ }^{1}$ National Center for Biotechnology \\ 13/5, Korgalzhyn road,, Astana, 010000, Kazakhstan \\ ${ }^{2}$ L.N. Gumilyov Eurasian National University \\ 2, Kanysh Satpayev street, Astana, 010008, Kazakhstan \\ aktayevasa@gmail.com
}

\begin{abstract}
There has been an increasing consumer demand for cheese along with a search for products with new organoleptic parameters, which has resulted in extensive research on alternative milk coagulants. The ratio of proteolytic activity to milk-clotting activity determines the requirements for proteases used in the cheese making process. To date, plant enzymes have largely been used for this purpose, along with traditional enzymes of animal origin, chymosin and pepsin. The most popular types of proteases used in the food industry, especially in cheese making, are plant proteases belonging to the cysteine (papain, bromelain, ficin), aspartate (cinarase, cardosin), and serine (kukumizin, leucine) group of proteases. The aspartate proteases of microbial origin mucorpepsin and endotyapepsin have found wide application in cheese production due to low production costs and high organoleptic characteristics of the final product. The use of plant and microbial milk-clotting enzymes as an alternative to animal-derived enzymes allows not only to diversify the assortment of cheeses on the market but also to solve ethical and economic issues. In addition, vegetable and microbial preparations meet the requirements of vegetarianism, halal, and kosher food, thus further opening the market.
\end{abstract}

Key words: milk coagulation, chymosin, vegetable rennet, microbial rennet.

\section{INTRODUCTION}

Milk and its products are among the main sources of human nutrition since the Neolithic revolution. According to the International Dairy Federation (IDF) in 2015, the production of all types of milk amounted to 818 million tons, which is $2 \%$ higher than in 2014 [1], and in 2016, according to "The Dairy News" with reference to IDF, this indicator reached 826 million tons. The main regions for milk production are India/Pakistan, the USA and Europe. The milk of the following animals is used in the production of dairy products: cows $(84 \%)$, buffalo $(12.1 \%)$, goats $(2 \%)$, sheep $(0.2 \%)$, camels $(0.2 \%)$, horses, donkeys and others animals $(0.4 \%)$.

Cheese is a product that has a special place in the diet of modern people. Due to the variability of the components used and the manufacturing technology, there is a huge number of types of cheese that differ in taste, smell and consistency. To date, experts disagree about the number of cheese types, and from 500 to 5000 names of cheese are given while attempting to classify [2]. The production of cheese is one of the most ancient food industries. Investigation of the remains of pottery from the Neolithic epoch in the territory of modern Poland made it possible to obtain evidence that already in the 5th millennium BC people processed milk, making cheese [3]. The production of cheese made it possible to solve several tasks: preserving the main components of milk (proteins, fats, vitamins) for a long time; transfer of milk into a solid form, which ensured more convenient transportation (which is relevant for nomadic peoples); the creation of a dairy product with a lower content of lactose, which makes it possible to solve the problem of lactase deficiency. In addition, milk processing allowed creation of a product that satisfies the taste preferences of a mostly any consumer.

The global cheese market shows stable growth. The main players in this market are the USA and the countries of the European Union. According to the USDA in 2016, the United States produced 5,514 thousand tons of cheese, and the EU 9,810 thousand tons. Despite the cessation of supply by the European Union of cheese to the Russian market, and through it to the CIS states, cheese production in the EU countries has increased. In the period 2013-2017 world cheese growth was 5\%.

Along with the US and European countries, major producers of cheeses are Russia, Brazil, Argentina, Canada and New Zealand. The largest growth rates in 2013-2017 are typical for New Zealand - 12.4\%. In 
addition, analysts noted the prospects for the cheese market in China - increasing both demand and supply - the annual increase is about 20\%. Among the reasons for the growing demand are the increase in income and changes in food habits.

In the period 2013-2017 the production of cheese and cottage cheese in the CIS countries went up by almost 20\%: from 1,313 thousand to 1,572 thousand tons. The largest increase in the production of cheese and cottage cheese was shown by Russia and Belarus - regional leaders in the field of cheese making. In 2013-2017 years Russian producers increased cheese and cottage cheese production by $34.5 \%$, and Belarusian producers by $32.1 \%$. According to BusinesStat, in 2018-2022 the production of cheese and cottage cheese in the CIS countries will grow at a rate of 1.1-2.3\% per year. In 2022 the cumulative output of cheese and cottage cheese in the region will reach 1,718 thousand tons, which will exceed the value of 2017 by $9.3 \%$.

Modern technology of cheese preparation includes the following stages: preparation of milk, milk coagulation with proteolytic enzymes and curd formation, cutting of a curd and separation of cheese grains from whey, kneading of cheese mass, pressing and maturing [4]. The use of various types of enzymes, bacterial and fungal starter cultures and formulations provides a variety of species $[4,5]$.

The presented review provides information on proteolytic enzymes used in cheese making.

\section{Enzymatic hydrolysis of casein}

Presumably, the first cheese was the result of the storage of milk in bags made from the stomachs of ruminants. Later, the active ingredients in this process were identified as proteolytic enzymes pepsin and chymosin, better known as "rennet" [2].

Bovine milk and, possibly, milk of other species, including buffalo, contain two markedly different groups of proteins, the paracaseins, which are phosphoproteins insoluble at $\mathrm{pH} 4.6$, and the whey (non-casein) proteins. Casein compose about $80 \%$ of the total amount of nitrogen in bovine milk and consists of four main proteins: alpha $S 1$, alpha $S 2$, beta $(\beta)$ and kappa $(\kappa)$ in the ratio of 40:10:35:12. All caseins are phosphorylated, and due to the high content of phosphate, alpha S1, alpha S2 and $\beta$-caseins bind $\mathrm{Ca}^{2+}$ strongly and precipitate. However, $\kappa$ casein, which has only one phosphate residue, binds calcium less and is more soluble at a high concentration of $\mathrm{Ca}^{2+}$ ions. Another feature of $\kappa$-casein is that, due to hydrophobic interaction with $\alpha$-S1, $\alpha$-S2 and $\beta$-caseins, it can stabilize and maintain them in the water-soluble state at a ratio exceeding 10 times its weight and preventing their precipitation by forming coarse colloidal aggregates.

In milk, more than $95 \%$ of caseins are presented in the form of large colloidal particles or micelles that precipitate during the coagulation of $\kappa$-casein. Coagulation of casein is a two-stage process: first, enzymatic production of para- $\kappa$-casein insoluble and macropeptides soluble in TCA (proteolytic stage) takes place. Curd is formed during the second stage (coagulation stage), as a result of the release of para- $\kappa$-casein and a precipitation as a calcium-bound casein at a temperatures greater than $20^{\circ} \mathrm{C}$ [6]. Depending on the specificity of the proteolytic enzymes, all or only individual components of the casein mixture are attacked. Thus, when chymosin is processed with a casein mixture, $\kappa$-casein is primarily cleaved, while the other casein fractions are least attacked. Enzymolysis of the $\kappa$-casein fraction is a calcium-dependent process. In the absence of calcium in the reaction system, the para- $\kappa$-casein fraction, which is itself insoluble, interacts with the other caseins and does not precipitate. If the reaction system contains calcium ions, the calcium-sensitive fraction of caseinate together with the insoluble fraction of para- $\kappa$-casein forms a clot (figure 1) [8]. 


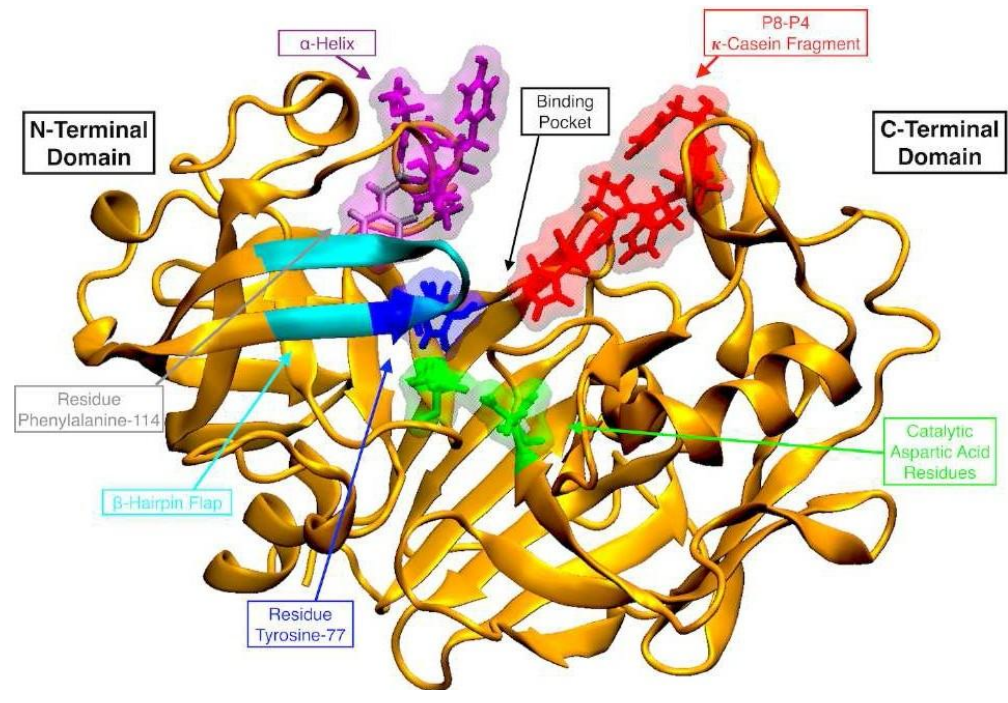

chymosin

kappa-Casein $\longrightarrow$ para-kappa-casein + glycomacropeptide (soluble in whey)

para-kappa-Casein $\underset{\mathrm{pH} \text { 6.4-6.0 }}{\stackrel{\mathrm{Ca}^{++}}{\longrightarrow}}$ dicalcium para-kappa-casein

Fig. 1. Destabilization of casein micelle by introduction of chymosin

Chymosin initiates the coagulation of milk by cleavage of the bond between $\mathrm{Phe}^{105}$ and Phe ${ }^{105}$ in the $\kappa$ casein molecule [8]. This bond is much more susceptible to acid proteases than other peptide bonds in the protein system of milk. The Phe-Met bond has a specific feature, so the dipheptide HPhe-MetOH, along with the tri- and tetrapeptides containing the Phe-Met bond, does not hydrolyze. At the same time, this bond is readily hydrolyzed in the pentapeptide, HSer-Ser-Phe-Met-Ala-OHze [8]. The length of the peptide and the sequence around the partitioned bond are important determinants of the interaction between the enzyme and the substrate. This circumstance imposes certain requirements on proteases used as milk coagulants.

\section{Animal derived milk coagulants}

All animal derived milk-clotting enzymes, widely used in cheesemaking, belong to acid proteases, showing maximum activity in an acidic environment. They are characterized by a high content of dicarboxylic amino acids and a low content of basic amino acids. They are also called aspartic proteases, because there are two residues of aspartate in their active center. Acid proteases contain 325-360 amino acid residues; their molecular mass is in the range of 33,000-38,000 $\mathrm{Da}$ [7]. In cheesemaking, the most known rennet enzymes are chymosin and pepsin.

Chymosin (EC 3.4.23.4) is derived from a calf's abomasum and is traditionally used as a milk coagulant for cheese production. Milk-coagulating enzymes containing chymosin are obtained from young animals of different species and each of them has its own specific biochemical characteristics [2]. Lamb and kid chymosins are also used and are almost identical to calf chymosin in amino acid composition [8]. As a rule, chymosins of cloven-hoofed animals have $\mathrm{pH}$ optimum at 4-4.7, while chymosins of predators are active under more acidic conditions, for example, cat-chymosin possesses optimal proteolytic activity at $\mathrm{pH} 2.5$ [8]. Like most proteases, chymosin is secreted in the inactivated form of zymogen prochymosin, and then is activated by autocatalytic proteolysis at a low $\mathrm{pH}$ value into the protein of chymosin with a molecular weight of $36 \mathrm{kDa}$. After activation, the enzyme destroys the $\kappa$-casein protein at a specific point and promotes the clot formation of milk. This process of milk curdling is used in the technology of cheese production.

Another proteolytic enzyme of animal origin which is used in cheesemaking is pepsin. Pepsin (EC 3.4.23.1) - an enzyme produced by the main cells of the gastric mucosa, carries out the cleavage of food proteins to peptides. It is present in the gastric juice of mammals, birds, reptiles and fish. The molecular weight of pepsin is about $34.5 \mathrm{kDa}$, the sequence contains 3 disulfide bonds. Pepsin belongs to the family of endopeptidases that break down internal peptide bonds in protein and peptide molecules with the formation of shorter peptides, and free amino acids. Pepsin is produced in an inactive form, and is activated in the lumen of 
the stomach after exposure to hydrochloric acid. In contrast to chymosin, the optimum $\mathrm{pH}$ of pepsin is in the range of 1.8-2.5. At an alkaline $\mathrm{pH}$, pepsin is completely inactivated. Pepsin, which is used in the cheesemaking, is obtained from the stomachs of cows, goats, pigs and birds [9].

The ability to rapidly hydrolyze $\kappa$-casein between $\mathrm{Phe}^{105}$ and $\mathrm{Met}^{106}$ in cheese-making is called milkclotting activity. This activity should be distinguished from the ability to cleave other bonds in proteins, called the general proteolytic activity. In cheesemaking, it is very important that the proteolytic / milk-clotting activity ratio is as low as possible. Milk-clotting enzymes differ significantly in relation to the total proteolytic activity of milk-coagulating. At the optimal $\mathrm{pH}$ for each enzyme and equal to the milk-clotting activity, the ratio of total proteolytic activity (by hemoglobin) of beef chymosin, beef and pork pepsins is 1:3:6. Chymosin has the lowest total proteolytic activity with respect to milk-clotting activity (12\%). Therefore, the most valuable and expensive cheeses are obtained using a rennet enzyme, in which the concentration of chymosin significantly prevails over the concentration of pepsin [10].

The higher total proteolytic activity of milk-coagulating enzymes in comparison with chymosin, as a rule, has a negative effect on the quality of cheeses, especially those with long maturation periods. For example, the loss of milk fat with whey was higher, and the density of the curd and the quality of the Cheddar cheese are lower when using pepsin instead of chymosin for coagulating milk. At the same time, a number of cheeses obtained using pure chymosin have a less pronounced taste and slowly ripen, compared to cheeses produced from the same milk and using the same technology, but with rennet powder, which is a mixture of chymosin and pepsin [11].

\section{Plant proteases in cheese making}

Ethical, religious and economic factors have led to the search for an alternative to animal derived rennet enzymes. Vegetable coagulants are used in cheese-making in addition to the enzymes obtained from animals. Their first documented mention refers to $42 \mathrm{AD}$ [12]. Thistle flowers (Carduus nutans), seeds of safflower dye (Carthamus tinctorius) and fig tree juice (Ficus carica) are mentioned among the substances that stimulate the coagulation of milk.

Plant proteases most often belong to the group of cysteine, aspartate and serine proteases. Cysteine proteases include enzymes isolated from Carica papaya (papain, chymopapain, caricaine, glycyl endopeptidase), Ananas comosus (bromelain, ananine, comozain) and Ficus glabrata and Ficus racemosa (ficin) $[12,13]$. Most plant cysteine proteases are involved in growth and development, aging and apoptosis [14], and they are also thought to be involved in protein mobilization, cellular signaling and response to biotic and abiotic effects [15]. Due to their high proteolytic activity, wide specificity and activity at various $\mathrm{pH}$ and temperature values, these enzymes have a high commercial potential.

Papain (EC 3.4.22.2, $23.4 \mathrm{kDa}$ ) is the most commonly used proteolytic enzyme of plant origin in food production [16]. The papain precursor consists of 345 amino acids, in which the first 18 are a signal peptide, following 115 are a propeptide and the remaining 212 amino acids are actually the protease itself (mature protein). The catalytic activity of papain is provided by the amino acid residues Cys ${ }^{25}$ and His ${ }^{159}$. An important role is played by $\mathrm{Asn}^{175}$, the interaction of which with imidazole ring of His ${ }^{159}$ provides the correct tertiary structure of the protein necessary for the deprotonation of the catalytic domain of Cys ${ }^{25}$ [17]. For the first time papain was isolated in 1879 from latex [12]. During the purification of the papain, reducing agents are used to preserve cysteine functions from air oxidation, which can lead to a decrease in the proteolytic activity of papain $[18,19]$. The optimal $\mathrm{pH}$ range for papain is quite wide (5.0-7.0) and varies depending on the nature of the substrate. In addition, papain is active in a wide temperature range $\left(10-90^{\circ} \mathrm{C}\right)[20]$. Another protease isolated from papaya is chymopapain (EC 3.4.22.6, $23.5 \mathrm{kDa}$ ) [12]. The precursor of chymopapain consists of 352 ao, but, in general, both papain and chymopapain have structural similarity. Both proteins contain three disulfide bonds and their active centers are almost identical. One more protease from Carica papaya - carikain (EC 3.4.22.30, $23.6 \mathrm{kDa}$ ) resembles papain and chymopapain.

Another protease, bromelain (EC 3.4.22.32, $22.8 \mathrm{kDa}$ ), was isolated from stems and immature pineapple fruits. The catalytic activity of bromelain is provided by $\mathrm{Cys}^{26}$ and $\mathrm{His}^{158}$. Bromelain is active at $\mathrm{pH} 6.0-8.5$ and at a temperature $50-60^{\circ} \mathrm{C}$. Alongside with bromelain from stems and pineapple fruit, other proteolytic enzymes have been found: ananain (EC 3.4.22.31, $25.5 \mathrm{kDa}$ ) and comozain[21]. Ficin (EC 3.4.22.3, 23.5 kDa) is a protease first isolated from the dry latex of the fig tree Ficus glabrata. In addition to F.glabrata ficin is also found in F. carica and F. elastica. One berry weighing $10-15 \mathrm{~g}$ contains up to $150 \mathrm{mg}$ of ficin. Ficin is active at $\mathrm{pH}$ 5.0-8.0 and at a temperature of $45-55^{\circ} \mathrm{C}$ [12]. In cheese-making, papain, bromelain and ficin are used as milk coagulants [22]. In particular in Indonesia, papain is used in the production of semi-soft Dangke cheese [23], and ficin is used in the production of traditional Turkish cheese, Gaziantep [24].

Aspartic proteases have two aspartic acid residues in the active site. Typically, aspartate proteases are most active in an acidic medium and are highly specific in the cleavage of peptide bonds between the hydrophobic amino acid residues of the substrate [25]. Aspartic proteases are responsible for the plant's response to stress, aging, apoptosis, sexual reproduction of plants [26] and perform antimicrobial functions [27]. 
It is known about the presence of aspartic proteases possessing the ability to coagulate milk in Saint-Marythistle Silybum marianum, artichoke Cynara scolymus, Turkish thistle Onopordum turcicum, maize thistle Centaurea calcitrapa and rice grains [16]. Potential sources of plant aspartic proteases are promising gymnosperms in which these proteases are widely distributed [29]. The most studied are aspartic proteases of the Spanish artichoke Cynara cardunculus, the flowers of which are traditionally used in the cheesemaking by the peoples of the Mediterranean region [30]. Heimgartner and colleagues identified three proteases that were named cinarase 1, 2 and 3. These heterodimeric proteases are only present in the violet part of flowers and have a molecular weight of about $49-50 \mathrm{kDa}$. In addition to these proteases, artichoke contains cardosin A and B [31]. Cardosin B has a higher specific proteolytic activity despite the fact that it is in less quantity than cardosin A. In addition to cardosins $\mathrm{A}$ and $\mathrm{B}$, four new aspartic proteases from flowers of $C$. cardunculus were isolated, purified, separated by the method of $2 \mathrm{D}$ gel electrophoresis and identified by the MALDI-TOF-TOF method: cardasins E, F, G and $\mathrm{H}$. The authors note a similarity in the biochemical parameters of cardosins A, E, F, G and $\mathrm{H}$ [32]. Plant aspartic proteases from the Asteraceae family mostly used in the production of cheese in the countries of the Mediterranean basin. For centuries, artichoke flowers were used in the preparation of goat and sheep's cheeses in the countries of East Africa and Southern Europe. These cheese products have a delicate creamy texture and an exquisite bitter taste. These organoleptic parameters are due to the broad substrate specificity of aspartic proteases that break down not only $\kappa$-casein, but also $\alpha$ - and $\beta$-casein. Proteases from leaves and roots of artichoke Cynara scolymus showed high milk-clotting activity.

Serine proteases containing serine in the active center are found in almost all taxonomic groups of plants and are present in almost all parts of plants, but in the greatest quantity in fruits. Plant serine proteases are involved in many physiological processes such as microsporogenesis, signal transduction that leads to the death of a hypersensitive cell [33]; differentiation of specialized plant tissues or organs and initiating mobilization of the carrier protein during early germination. The molecular weight of serine proteases of plant origin varies from 19 to $110 \mathrm{kDa}$. Plant serine proteases are active over a wide range of $\mathrm{pH} 7-11$, and temperature $20-50^{\circ} \mathrm{C}$ [12]. Cucumis melo sarcocarpus contains a high concentration of serine protease cucumisin (EC 3.4.21.25, 67.1 kDa), which has a structural similarity to subtilisin [34]. This enzyme exhibits high proteolytic and milk-clotting activity. Cucumisin with the same milk-clotting activity as papain, produces much less peptides with bitter degradation than those that were formed by other plant proteases [35]. Another enzyme of the serine group, lettucin, from the leaves of Lactuca sativa, is capable of provoking considerable disorganization of the micellar structure of casein and the results of proteolytic activity are similar to the process of coagulation of milk [36].

The high milk-coagulating activity was shown by protein extracts from the seeds of Albizia lebbeck and Helianthus annuus seeds. Moreover, the extract from A. lebbeck seeds has 15 times more coagulation activity than the extract from sunflower seeds [37]. Actinidain (EC 3.4.22.14, $24 \mathrm{kDa}$ ), isolated from mature kiwi fruits, also has a milk-clotting activity [38]. Another promising protease with milk-clotting activity is a glycoprotein with a molecular weight of $36 \mathrm{kDa}$, isolated from the roots of ginger Zingiber officinale [39].

Besides the isolation of proteases from plant matter, there is a great interest to methods for producing them in vitro by micropropagation, callus and cell suspension cultures and cultures of transformed roots is of great interest. The application of these technologies has a number of advantages, the main of which is the possibility of obtaining a large amount of a homogeneous protease, which makes production economically feasible. In addition, these biotechnological methods of obtaining raw materials in laboratory conditions allow independence from climatic and seasonal conditions and to shorten the time necessary to produce the final product and overcome the difficulties arising from the extraction of enzymes from natural raw materials [40].

\section{Microbial milk coagulants}

Substitution of animal rennet may be performed not only by plant proteases, but by pepsin-like enzymes of microbial origin. Advantages of microbial enzymes: low cost of production, compliance with the criteria of natural origin and vegetarian requirements. Already in 1974, the proteases Rhizomucor miehei, R. pussilus and Cryphonectria parastica were used in the production of $60 \%$ of cheese made in the USA. These filamentous fungi that produce milk-coagulating enzymes remain to be of greatest interest for cheese-making today.

The aspartate protease obtained from $R$. miehei and $R$. pussilus has a three-dimensional structure similar to that of chymosin, called mucorpepsin (EC 3.4.23.23) and is the most common rennet enzyme of microbiological origin. This protease cleaves $\kappa$-casein into glycomacropeptide and para- $\kappa$-casein by hydrolyzing only the peptide bond Phe ${ }^{105}$ and Met $^{106}$ [41]. The precursor of mucorpepsin, obtained from R. pussilus, consists of 437 amino acids, 22 of which are signal peptides, the following 44 amino acids are propeptide, and 361 amino acids constitute a mature protease. In the case of $R$. miehei, the precursor comprises a signal peptide of 22 amino acids, a propeptide from 47 amino acids, and a mature protease from 361 amino acids [42].

Endotiapepsin (EC 3.4.23.22) is produced by C. parastica. The precursor consists of 419 amino acids, the signal peptide consists of 20 amino acids, the propeptide of 69 amino acids, the mature enzyme includes 330 amino acids. Initially, the milk-binding properties of endotiapepsin were attributed to the cleavage of Phe ${ }^{105}$ and $\mathrm{Met}^{106}$, but subsequent studies showed that the enzyme acts on the neighboring Ser ${ }^{104}-\mathrm{Phe}^{105}$ peptide bond in the 
$\kappa$-casein molecule [42]. A particular feature of this protease is its high thermolability, due to which endotiapepsin has found wide application in the production of cheeses such as Cheddar, Swiss, Colby and Italian, the technology of preparation of which imposes certain requirements on the properties of the enzyme used. Cheeses made using endotiapepsin are evaluated by cheese experts as equivalent to or even superior in quality than control cheeses produced using animal chymosin [22].

\section{Known commercial preparations}

Dairy enzymes market in 2016 was estimated at 492.2 million US dollars, and by 2020 it is projected to grow to 734.6 million US dollars. The reasons for expecting such a rapid growth is an increase in the consumption of cheese and, in particular, rennet cheese. About $70 \%$ of cheese produced in the US, and $33 \%$ of cheese produced in other countries, are obtained using rennet enzymes.

The main world producers of enzymes for cheese making are: Osterreichische Laberzeugung Hundsbichler GmbH (Austria); Renco New Zealand (New Zealand); Chr. Hansen (Denmark); Danisco Dupont (Denmark); Mittal Dairy Product (India); Clarion Casein Ltd (India); Fonterra (New Zealand); WalcoRen (Canada); Mahaan Proteins Limited (India); Sanmenxia Enzymes Products Factory (China); Enzyme Supplies Limited (United Kingdom).

The CIS ferments market is dominated by the Russian producers: Endocrine Enzymes Plant, Moscow Rennet Enzyme Plant. In the production of milk-clotting enzymes, these enterprises use chymosin, beef and chicken pepsin in various proportions. Apart from animal enzymes there are commercial plant and microbial proteases on the market. Microbial rennet "Meito", which is produced by the Japanese company Meito Sangyo Co., Ltd., is the most frequent microbial enzyme on the markets of Kazakhstan and Russia. It is a series of microbial coagulants produced by the fungi $R$. pusillus and $R$. miehei.

Currently, the following types of preparations are presented on the dairy enzymes market (table 1).

Table 1. Commercially available proteases

\begin{tabular}{|c|c|c|}
\hline Trademark & Manufakturer & Enzyme \\
\hline \multicolumn{3}{|c|}{ Preparations based on animal derived rennet } \\
\hline Tradition & Endocrine Enzymes Plant (Russia) & $\begin{array}{l}\text { Calf chymosin (0-90\%) and pepsin (bovine, } \\
\text { chicken) }\end{array}$ \\
\hline Extra & $\begin{array}{l}\text { Moscow Rennet Fermented Plant } \\
\text { (Russia) }\end{array}$ & $\begin{array}{l}\text { Calf chymosin }(0-90 \%) \text { and pepsin } \\
\text { (bovine,porcine, chicken) }\end{array}$ \\
\hline AmericanPure & Sanofi Bio-Industries (USA) & $\begin{array}{l}\text { Calf rennet enzyme preparation purified by ion } \\
\text { exchange chromatography }\end{array}$ \\
\hline BIOREN & Hundsbichler GmbH (Germany) & $\begin{array}{l}\text { Calf rennet enzyme preparation with a content } \\
\text { of chymosin from } 50 \% \text { to } 94 \%\end{array}$ \\
\hline Clerici & Caglifico Clerici (Italy) & $\begin{array}{l}\text { Calf rennet enzyme preparation with a content } \\
\text { of chymosin from } 20 \% \text { to } 96 \%\end{array}$ \\
\hline Kalase ${ }^{\circledR}$ & 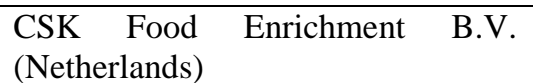 & $\begin{array}{l}\text { Calf rennet enzyme preparation with a content } \\
\text { of chymosin } 80 \%\end{array}$ \\
\hline $\begin{array}{l}\text { Carlina }{ }^{\mathrm{TM}} \text { Animal } \\
\text { Rennet }\end{array}$ & Danisco (France) & $\begin{array}{l}\text { Calf rennet enzyme preparation with a content } \\
\text { of chymosin from } 25 \% \text { to } 80 \%\end{array}$ \\
\hline NATUREN® & CHR HANSEN (Denmark) & $\begin{array}{l}\text { Calf rennet enzyme preparation with a content } \\
\text { of chymosin from } 20 \% \text { to } 96 \%\end{array}$ \\
\hline \multicolumn{3}{|c|}{ Preparations based on plant derived enzymes } \\
\hline Papain & $\begin{array}{l}\text { Senthil Papain and Food Products } \\
\text { (P) Ltd. (India), Fruzyme Biotech } \\
\text { India Pvt Ltd. (India), Shri Ganesh } \\
\text { Industrial Enzymes (India) }\end{array}$ & Papain \\
\hline Bromelain & $\begin{array}{l}\text { Enzybel International } \\
\text { (Belgium), S.A. } \\
\text { Biochemicals Co., Ltd. (Thailand), } \\
\text { Nanning Pangbo Bioengineering } \\
\text { Co. Ltd. (China) }\end{array}$ & Bromelain \\
\hline Ficin & $\begin{array}{l}\text { Enzybel International S.A. } \\
\text { (Belgium), Geno Technology Inc. } \\
\text { (U.S.A.), Merck KGaA (Germany) }\end{array}$ & Ficin \\
\hline \multicolumn{3}{|c|}{ Preparations based on fermentation products of the strain Cryphonectria parasitica } \\
\hline Thermolase $\AA$ & Chr. Hansen (Denmark) & Endotiapepsin \\
\hline
\end{tabular}




\begin{tabular}{|c|c|c|}
\hline Suparen ${ }^{\circledR}$ & Dsm, Netherlands & Endotiapepsin \\
\hline \multicolumn{3}{|c|}{ Preparations based on fermentation products of R. pusillus and/or R. miehei strains } \\
\hline Hannilase $\AA$ & Chr. Hansen (Denmark) & Mucorpepsin \\
\hline Fromase $\AA$ & Dsm (Netherlands) & Mucorpepsin \\
\hline Meito rennet super ${ }^{\circledR}$ & Meito Sangyo Co. (Japan) & Mucorpepsin \\
\hline Milase ${ }^{\circledR}$ & $\begin{array}{lll}\begin{array}{l}\text { CSK food enrichment } \\
\text { (Netherlands) }\end{array} & \\
\end{array}$ & Mucorpepsin \\
\hline Valiren ${ }^{\circledR}$ & MAYASAN (Turkey) & Mucorpepsin \\
\hline Enzymaks ${ }^{\circledR}$ & $\begin{array}{l}\text { Iran Industrial Enzymes Company } \\
\text { (Iran) }\end{array}$ & Mucorpepsin \\
\hline Reniplus $\AA$ & Grupo Proquiga (Spain) & Mucorpepsin \\
\hline $\begin{array}{ll}\text { Sumizyme } & \text { MMR } \\
\text { TL® } & \\
\end{array}$ & Hundsbichler GmbH (Austria) & Mucorpepsin \\
\hline Microclerici $₫$ & Caglificio Clerici (Italy) & Mucorpepsin \\
\hline Marzyme ${ }^{\circledR}$ & Danisco (France) & Mucorpepsin \\
\hline Marshall ${ }^{\circledR}$ & Danisco (France) & Mucorpepsin \\
\hline $\begin{array}{ll}\text { Meito } & \text { microbial } \\
\text { rennet }{ }^{\circledR}\end{array}$ & Meito Sangyo Co. (Japan) & Mucorpepsin \\
\hline
\end{tabular}

\section{CONCLUSION}

To date, the cheese market is one of the most massive food markets in Kazakhstan. The average annual cheese consumption in Kazakhstan is $2.5 \mathrm{~kg}$ per capita. According to the Statistics Committee of the Ministry of Economy of the Republic of Kazakhstan, the capacity of the Kazakhstan market in 2016 amounted to 44,825 tons per year. According to marketing research, this indicator is predicted to increase to 45,211 tons in 2018 and 45,938 tons in 2019. It is worth noting that the share of imports in the domestic market remains significant $46.34 \%$. Russia, Ukraine, Belarus are the top three importers. In general, the increase in the domestic production of cheese and cottage cheese in the first half of 2016 compared to the same period in 2015 amounted to 502 tons or $6.9 \%$ [43].

Along with the growth of cheese production, the demand for enzyme preparations is also increasing. Traditional cheese production is still based on animal rennet: chymosin and pepsin. However, for a number of properties, preparations of microbial origin are not inferior to preparations based on animal enzymes. Vegetable coagulants are also promising. The attractiveness of the use of plant proteases in cheesemaking is due to the fact that such preparations meet the requirements for labeling kosher, halal and vegetarian food. Despite the abundance of enzyme preparations, the search for new enzymes of plant and microbial origin continues, which is conditioned by the demand not only for natural products, but also for products characterized by special organoleptic parameters.

One of the features of the Kazakhstan cheese market is the complete absence of domestic-made enzyme preparations, which forces cheese producers to purchase coagulants abroad. Creation of own production is associated with temporary production costs and requires scientific capacity building. Nevertheless, it is necessary to conduct work on the development and organization of dairy enzymes production, since this aspect is directly related to such topical areas as deep processing of milk and the country's food security.

\section{Fundings}

This work was carried out with the financial support of the Ministry of Education and Science of the Republic of Kazakhstan in the framework of the scientific project No. AP05133470 for 2018-2020.

\section{REFERENCES}

1. The World Dairy Situation 2016. International Dairy Federation: Brussels, 2016, 259 p.

2. McSweeney P.L.H., ed. Cheese problems solved. Woodhead Publishing Limited., 2007, 424 p.

3. Salque M., Bogucki P.I., Pyzel J., Sobkowiak-Tabaka I., Grygiel R., Szmyt M., Evershed R.P. Earliest evidence for cheese making in the sixth millennium BC in northern Europe. Nature, 2013, vol. 493, no. 7433, pp. 522-525.

4. Law B.A., Tamime A.Y., eds. Technology of Cheesemaking. 2nd ed. Wiley-Blackwell, 2010, 512 p.

5. Bergamaschi M., Bittante G. From milk to cheese: Evolution of flavor fingerprint of milk, cream, curd, whey, ricotta, scotta, and ripened cheese obtained during summer Alpine pasture. J Dairy Sci, 2018, vol. 101, no. 5, pp. 3918-3934. 
6. McSweeney P.L.H. Biochemistry of cheese ripening. International Journal of Dairy Technology, 2004, vol. 57, no. 2-3, pp. 127-144.

7. Repelius K., Yarkina D.M. Molokosvertyvayushchiye fermentnyye preparaty i ikh rol' v syrodelii (Milk-clotting enzyme preparations and their role in cheese making). Pererabotka moloka (Processing of milk), 2004, no. 4, pp. 22-23.

8. Kumar A., Grover S., Sharma J., Batish V.K. Chymosin and other milk coagulants: sources and biotechnological interventions. Critical Reviews in Biotechnology, 2010, vol. 30, no. 4, pp. 243-258.

9. Kaneko J.J., Harvey J.W., Bruss M.L. eds. Clinical Biochemistry of Domestic Animals. 6th ed. Elsevier Inc., 2008, 928 p.

10. Krajushkin V.A., Buzov I.P. Kontrol' aktivnosti molokosvertyvayushchikh fermentnykh preparatov (Control of the activity of lactiferous enzyme preparations). Syrodeliye $i$ maslodeliye (Cheese and butter making), 2005, no. 4, pp. 23-24.

11. Gudkov S.A., ed. SYRODELIYE: tekhnologicheskiye, biologicheskiye i fiziko-khimicheskiye aspekty (CHEESE: technological, biological and physico-chemical aspects). 2 ed. DeLi Print: Moscow, 2004, 800 p.

12. Feijoo-Siota L., Villa T.G. Native and Biotechnologically Engineered Plant Proteases with Industrial Applications. Food and Bioprocess Technology, 2011, vol. 4, no. 6, pp. 1066-1088.

13. Devaraj K.B., Gowda L.R., Prakash V. An unusual thermostable aspartic protease from the latex of Ficus racemosa (L.). Phytochemistry, 2008, vol. 69, no. 3, pp. 647-655.

14. Martinez D.E., Bartoli C.G., Grbic V., Guiamet J.J. Vacuolar cysteine proteases of wheat (Triticum aestivum L.) are common to leaf senescence induced by different factors. J Exp Bot, 2007, vol. 58, no. 5, pp. 1099-1107.

15. van der Hoorn R.A., Jones J.D. The plant proteolytic machinery and its role in defence. Curr Opin Plant Biol, 2004, vol. 7, no. 4, pp. 400-407.

16. Shah M.A., Mir S.A., Paray M.A. Plant proteases as milk-clotting enzymes in cheesemaking: A review. Dairy Science \& Technology, 2014, vol. 94, no. 1, pp. 5-16.

17. Amri E., Mamboya F. Papain, a plant enzyme of biological importance: a review. American Journal of Biochemistry and Biotechnology, 2012, vol. 8, no. 2, pp. 99-104.

18. Monti R., Carmelita A.B., Henrique C.T., Contiero J. Purification of papain from fresh latex of Carica papaya. Brazilian Archives of Biology and Technology, 2000, vol. 43, no. 5, pp. 501-507.

19. Azarkan M., El Moussaoui A., van Wuytswinkel D., Dehon G., Looze Y. Fractionation and purification of the enzymes stored in the latex of Carica papaya. J Chromatogr B Analyt Technol Biomed Life Sci, 2003, vol. 790, no. 1-2, pp. 229-238.

20. Whitehurst R.J., Maarten M.O. Enzymes in food technology. 2nd ed., Chichester, U.K, WileyBlackwell, 2010, 384 p.

21. Zatul Iffah Mohd Arshad \& Azura Amid \& Faridah Yusof \& Irwandi Jaswir \& Kausar Ahmad \& Show Pau Loke. Bromelain: an overview of industrial application and purification strategies. Appl Microbiol Biotechnol, 2014, no. 98, pp. 7283-7297.

22. Polaina J., MacCabe A.P. Industrial enzymes: structure, function, and applications. Dordrecht: Springer, 2007, $641 \mathrm{p}$.

23. Prasetyo H., Kartawiria I.S., Marpaung A.M. Optimization of Papain Enzyme Utilization in NonRennet Cream Cheese Production. International Conference on Innovation, Entrepreneurship and Technology. BSD City, Indonesia, 2015, pp. 205-210.

24. Lo Piero A.R., Puglisi I., Petrone G. Characterization of the purified actinidin as a plant coagulant of bovine milk. Eur Food Res Technol, 2011, vol. 233, pp. 517-524.

25. Domingos A., Cardoso P.C., Xue Z.T., Clemente A., Brodelius P.E., Pais M.S. Purification, cloning and autoproteolytic processing of an aspartic proteinase from Centaurea calcitrapa. Eur J Biochem, 2000 , vol. 267, no. 23, pp. 6824-6831.

26. Simoes I., Faro C. Structure and function of plant aspartic proteinases. Eur J Biochem, 2004, vol. 271, no. 11, pp. 2067-2075.

27. Mendieta J.R., Pagano M.R., Munoz F.F., Daleo G.R., Guevara M.G. Antimicrobial activity of potato aspartic proteases (StAPs) involves membrane permeabilization. Microbiology, 2006, vol. 152, Pt 7, pp. 20392047.

28. Vairo-Cavalli S., Claver S., Priolo N., Natalucci C. Extraction and partial characterization of a coagulant preparation from Silybum marianum flowers. Its action on bovine caseinate. J Dairy Res, 2005 , vol. 72 , no. 3, pp. 271-275.

29. Simôes I., Faro C. Structure and function of plant aspartic proteinases. European Journal of Biochemistry, 2004, vol. 271, no. 11, pp. 2067-2075.

30. Silva S.V., Pihlanto A., Malcata F.X. Bioactive peptides in ovine and caprine cheeselike systems prepared with proteases from Cynara cardunculus. J Dairy Sci, 2006, vol. 89, no. 9, pp. 3336-3344. 
31. Lamas E.M., Barros R.M., Balcao V.M., Malcata F.X. Hydrolysis of whey proteins by proteases extracted from Cynara cardunculus and immobilized onto highly activated supports. Enzyme Microb Technol, 2001, vol. 28, no. 7-8, pp. 642-652.

32. Ben Amira A., Bauwens J., De Pauw E., Besbes S., Attia H., Francis F., Blecker C. Identification of proteins from wild cardoon flowers (Cynara cardunculus L.) by a proteomic approach. J Chem Biol, 2017 , vol. 10 , no. 1 , pp. 25-33.

33. Coffeen W.C., Wolpert T.J. Purification and characterization of serine proteases that exhibit caspaselike activity and are associated with programmed cell death in Avena sativa. Plant Cell, 2004, vol. 16, no. 4, pp. 857-873.

34. Sotokawauchi A., Kato-Murayama M., Murayama K., Hosaka T., Maeda I., Onjo M., Ohsawa N., Kato D.I., Arima K., Shirouzu M. Structural basis of cucumisin protease activity regulation by its propeptide. $J$ Biochem, 2017, vol. 161, no. 1, pp. 45-53.

35. Mazorra-Manzano M.A., Perea-Gutiérrez T.C., Lugo-Sánchez M.E., Ramirez-Suarez J.C., TorresLlanez M.J., González-Córdova A.F., Vallejo-Cordoba B. Comparison of the milk-clotting properties of three plant extracts. Food Chemistry, 2013, vol. 141, no. 3, pp. 1902-1907.

36. Lo Piero A.R., Puglisi I., Petrone G. Characterization of "lettucine", a serine-like protease from Lactuca sativa leaves, as a novel enzyme for milk clotting. J Agric Food Chem, 2002, vol. 50, no. 8, pp. 24392443.

37. Egito A.S., Girardet J.M., Laguna L.E., Poirson C., Mollé D., Miclo L., Humbert G., Gaillard J.L. Milk-clotting activity of enzyme extracts from sunflower and albizia seeds and specific hydrolysis of bovine $\kappa$ casein. International Dairy Journal, 2007, vol. 17, no. 7, pp. 816-825.

38. Katsaros G.I., Tavantzis G., Taoukis P.S. Production of novel dairy products using actinidin and high pressure as enzyme activity regulator. Innovative Food Science \& Emerging Technologies, 2010, vol. 11, no. 1, pp. 47-51.

39. Hashim M.M., Mingsheng D., Iqbal M.F., Xiaohong C. Ginger rhizome as a potential source of milk coagulating cysteine protease. Phytochemistry, 2011, vol. 72, no. 6, pp. 458-464.

40. Gonzalez-Rabade N., Badillo-Corona J.A., Aranda-Barradas J.S., Oliver-Salvador Mdel C. Production of plant proteases in vivo and in vitro-a review. Biotechnol Adv, 2011, vol. 29, no. 6, pp. 983-996.

41. Neelakantan S., Mohanty A.K., Kaushik J.K. Production and use of microbial enzymes for dairy processing. Current Science, 1999, vol. 77, no. 1, pp. 143-148.

42. Feijoo-Siota L., Blasco L., Luis Rodriguez-Rama J., Barros-Velázquez J., de Miguel T., SanchezPerez A., Villa T., Recent Patents on Microbial Proteases for the Dairy Industry. Recent Adv DNA Gene Seq, 2014, vol. 8, pp. 44-55.

43. Energyprom

Review.

Available

at: http://www.energyprom.kz/a/reviews/bemy_proizvodstva_molochnoj_produkcii_za_janvarmaj_vyrosli_na_88_ do_701_mlrd_tenge_v_godovom_sopostavlenii_v_naturalnom_vyrazhenii_dinamika_po_razlichnym_vidam_pr odukcii_raznonapravlennaja?mcode=markets (accessed: 05/05/2018). 